\title{
Optimasi Proses Pada Fungsi Pengelolaan Fasilitas Dalam Perancangan Arsitektur Bisnis Menggunakan TOGAF ADM
}

\author{
Meidiani Juwita Rachmawati ${ }^{1}$, Asti Amalia Nur Fajrillah ${ }^{2}$ \\ Jurusan Sistem Informasi, Fakultas Rekayasa Industri, Universitas Telkom, Bandung, Indonesia \\ Email: mjuwitar2@gmail.com
}

\begin{abstract}
In this digital era, the expansion of information technology has made IT a way for companies to achieve their goals. Not only helps in the work process but also can be a solution to problems and achieve the company strategies. In the process of implementing IT, design is needed with in-depth analysis in accordance with company conditions. It is intended that IT applied can be a solution, strategy, effective and efficient for the company. The development of IT also encourages manufacturing type companies to continue to grow. In one of the manufacturing companies in Bandung, especially in the Facility Management Function, there are constraints, namely asset control and application needs. This has become the driving force for manufacturing companies to develop IT in their companies. One of the tools for creating information technology that is in line with business goals is to use Enterprise Architecture (EA). Through EA can maximize investment in the use of IT in an organization. In this study, EA design uses The Open Group Architecture Framework (TOGAF ADM). This research was conducted at a manufacturing company in Bandung and focused from the preliminary phase to the business architecture phase, on the Facility Management Function and using the TOGAF ADM framework. This study uses descriptive methods and aims to provide business architecture design as a solution to the facility management function to optimize business processes and by using IT.
\end{abstract}

Keywords: Enterprise Architecture, EA, Facility Management, Business Architecture, TOGAF ADM

\begin{abstract}
ABSTRAK
Pada era - digital ini, perkembangan teknologi informasi menjadikan TI sebagai cara bagi perusahaan untuk mencapai tujuannya. Tidak hanya membantu dalam proses pekerjaan namun juga dapat menjadi solusi dari sebuah permasalahan dan strategi bagi perusahaan. Dalam proses pengimplementasian TI, diperlukan perancangan dengan analisis yang mendalam sesuai dengan kondisi perusahaan. Hal ini bertujuan agar TI yang diterapkan dapat menjadi solusi, strategi, efektif dan efisien bagi perusahaan. Perkembangan TI ini juga mendorong perusahaan tipe manufaktur untuk terus berkembang. Pada salah satu perusahaan manufaktur di Bandung khususnya pada Fungsi Pengelolaan Fasilitas, mengalami kendala yaitu pada kontrol aset dan kebutuhan aplikasi. Hal ini menjadi pendorong perusahaan manufaktur tersebut untuk mengembangkan TI pada perusahaannya. Salah satu tools untuk menciptakan teknologi informasi yang sejalan dengan tujuan bisnis adalah dengan menggunakan Enterprise Architecture (EA). Melalui EA dapat memaksimalkan investasi penggunaan TI pada suatu organisasi. Pada penelitian ini, perancangan EA menggunakan framework The Open Group Architecture Framework (TOGAF ADM). Penelitian ini dilakukan pada perusahaan manufaktur di Bandung dan berfokus mulai dari fase preliminary hingga fase business architecture, pada fungsi pengelolaan fasilitas dan menggunakan framework TOGAF ADM. Penelitian ini menggunakan metode descriptive dan bertujuan untuk memberikan perancangan arsitektur bisnis sebagai solusi pada fungsi pengelolaan fasilitas untuk mengoptimalkan proses bisnisnya dan dengan menggunakan TI.
\end{abstract}

Kata Kunci: Enterprise Architecture, EA, Fungsi Pengelolaan Fasilitas, Arsitektur Bisnis, TOGAF ADM

\section{Pendahuluan}

Teknologi informasi menjadi elemen dasar yang perlu dimiliki oleh perusahan atau organisasi untuk mempermudah proses pengambilan keputusan[1]. Saat ini, teknologi tidak dapat dipisahkan dari jalannya sebuah organisasi karena teknologi informasi merupakan salah satu sumber daya yang 
Meidiani Juwita Rachmawati ${ }^{1}$, Asti Amalia Nur Fajrillah ${ }^{2}$

@is The Best: Accounting Information Systems and Information Technology Business Enterprise ISSN: 2252-9853 (Print) | ISSN: 2656-808X (Online)

dapat meningkatkan kompetensi dan strategi untuk membantu visi, misi dan target perusahaan tercapai.

Kebutuhan akan teknologi informasi juga dirasakan oleh perusahaan tipe industri dan manufaktur. Perkembangan industri telah memasuki ke tahap industri 4.0. Industri 4.0 secara signifikan meningkatkan produktivitas, efisiensi, self-managing produksi, dimana manusia, mesin, peralatan, sistem logistik dan komponen work - in - process saling berkomunikasi dan bekerja sama secara langsung[2]. Hal ini menjadi tantangan bagi industri manufaktur untuk mengoptimalkan dan mengevaluasi proses bisnisnya agar dapat terus bersaing dan menyesuaikan dengan cepat[3]. Dengan demikian, perusahaan industri manufaktur perlu menerapkan teknologi informasi yang sesuai dengan kondisi saat ini dan kebutuhannya untuk dapat terus bersaing.

Fungsi yang terdapat pada perusahaan manufaktur salah satunya adalah fungsi pengelolaan fasilitas. Fungsi ini bertanggung jawab untuk mengelola, menjaga, mendata seluruh fasilitas yang perusahaan. Di sebuah perusahaan manufaktur yang berlokasi di Bandung, fungsi ini mengalami kendala diantaranya adalah pendataan fasilitas yang tidak ter-update. Terdapat $50 \%$ data yang tidak ter-update pada pendataan aset dan belum adanya teknologi informasi yang mampu mendukung proses pengerjaan aktivitas fungsi pengelolaan fasilitas untuk menghasilkan kinerja yang maksimal, efektif dan efisien. Fungsi pengelolaan fasilitas di sebuah perusahaan manufaktur tersebut hanya menggunakan Microsoft word, Microsoft excel, e-mail, telepon dan surat-menyurat dalam bentuk fisik untuk menunjang proses bisnisnya. Hal ini menjadi tantangan untuk fungsi pengelolaan fasilitas dan untuk perusahaan. Proses pengerjaan aktivitas yang lamban membuat perusahaan tidak dapat maju dengan cepat dan bersaing. Pengelolaan proses bisnis yang tepat dapat meningkatkan kinerja organisasi secara keseluruhan[4].

Salah satu solusi untuk permasalahan tersebut adalah membuat perancangan enterprise architecture (EA). EA adalah suatu pendekatan hierarkis yang bertujuan untuk menyelaraskan strategi bisnis dan strategi TI pada sebuah perusahaan dengan mengintegrasikan sistem informasi, proses bisnis, unit organisasi dan stakeholder[5]. EA menggambarkan rencana untuk pengembangan sistem maupun sekumpulan sistem[6]. Implementasi EA yang didasarkan pada requirement bisnis lebih efektif dibandingkan didasarkan pada technical concerns[7].

Dalam perancangan EA salah satu framework yang sering digunakan adalah The Open Group of Architecture Framework (TOGAF). TOGAF banyak digunakan di berbagai industri, diantaranya adalah perbankan, manufaktur dan pendidikan. TOGAF dapat didefinisikan sebagai framework yang diperuntukkan untuk segala jenis organisasi di dunia[8]. TOGAF dipercaya pada menjadi framework untuk solusi pada sebuah perusahaan manufaktur yang bergerak di bidang pengelolaan kelapa sawit karena sifatnya yang iterative sehingga menghasilkan perancangan SI/TI yang mendukung proses bisnis yang lebih efektif dan efisien[9]. Dengan sifatnya yang iterative dan dapat menghasilkan perancangan proses bisnis yang lebih efektif dengan dukungan SI/TI, TOGAF dapat digunakan sebagai framework untuk mengoptimalisasikan proses bisnis pada perusahaan dengan dukungan teknologi informasi.

Penelitian terdahulu yang dijadikan referensi pada penelitian ini adalah penelitian yang ditulis oleh Rengga Eko Riwanto dan Johanes Fernandes Andry dengan judul 'Designing Enterprise Architecture Enable of Business Strategy and IS/TI Alignment in Manufacturing using TOGAF ADM Framework[9]. Penelitian ini dijadikan referensi karena adanya kemiripan masalah dan tujuan dari penelitian. Namun pada penelitian ini tidak dijabarkan dan dipetakan proses bisnis beserta deskripsinya dan aplikasi yang digunakan pada kondisi eksisting beserta keterkaitannya dengan masalah yang ada. Penjabaran mengenai keterkaitan antara proses bisnis, aplikasi, permasalahan

Volume 5 Nomor 1 (2020) Hal. 76-90 
Meidiani Juwita Rachmawati ${ }^{1}$, Asti Amalia Nur Fajrillah ${ }^{2}$

@is The Best: Accounting Information Systems and Information Technology Business Enterprise

ISSN: 2252-9853 (Print) | ISSN: 2656-808X (Online)

serta goal penting untuk digambarkan sehingga solusi yang diberikan dapat sesuai dan tepat sasaran. Oleh karena itu, diharapkan penelitian ini dapat menyempurnakan penelitian sebelumnya.

\section{Kerangka Teoritis}

\section{Enterprise Architecture}

EA dapat diartikan sebagai definisi dan representasi tingkat tinggi dari proses bisnis perusahaan dan sistem TI serta hubungan keduanya[10]. EA merupakan pendekatan yang berfungsi untuk mengelola dan mengembangkan organisasi, mengadopsi pandangan proses bisnis, sistem informasi dan infrastruktur teknologi[11]. Tujuan utama EA adalah untuk mencapai misi organisasi dengan mengurangi biaya sesuai dengan sistem SI / TI yang diterapkan dan menyelaraskan sistem dengan tujuan bisnis mereka[12]. Berdasarkan teori - teori tersebut secara garis besar EA merupakan sebuah pendekatan yang digunakan untuk menyelaraskan proses bisnis dengan teknologi informasi untuk menghasilkan proses yang efektif dan efisien sehingga dapat menjadi strategi untuk tercapainya tujuan perusahaan.

\section{TOGAF ADM}

TOGAF merupakan sebuah kerangka kerja untuk membangun EA[13]. TOGAF adalah kerangka arsitektur-metode yang detail dan seperangkat alat pendukung-untuk mengembangkan sebuah arsitektur enterprise[14]. TOGAF merupakan framework architecture yang memberikan pendekatan komprehensif untuk perencanaan, perancangan, evaluasi, pembangunan dan penerapan arsitektur yang tepat untuk suatu organisasi[15]. Penggunaan framework. TOGAF untuk perancangan arsitektur khususnya untuk perusahaan manufaktur karena TOGAF mampu memberikan implementasi yang sederhana dan keselarasan antara bisnis dan SI/TI yang baik[16]. TOGAF memberikan metode yang detail tentang bagaimana membangun, mengelola serta mengimplementasikan enterprise architecture dan sistem informasi yang disebut dengan Architecture Development Method (ADM)[17].

ADM mendeskripsikan apa yang perlu dilakukan untuk membuat arsitektur[18]. ADM dapat diadaptasi untuk berbagai keperluan dan dalam situasi yang lebih kompleks, arsitektur dapat dibatasi dan di partisi sehingga beberapa arsitektur dapat dikembangkan dan kemudian diintegrasikan[19]. TOGAF ADM mempunyai beberapa fase diantaranya[20]:

\section{Preliminary Phase}

Tahap persiapan dan inisiasi perancangan EA, pendefinisian framework arsitektur dan prinsip - prinsip yang digunakan selama perancangan EA

2. Fase A: Architecture Vision

Pendefinisian ruang lingkup dari perancangan arsitektur, mengidentifikasi stakeholder dan membuat visi arsitektur

\section{Fase B: Business Architecture}

Mendefinisikan pengembangan dari arsitektur bisnis untuk mendukung Fase A: Architecture Vision, menetapkan baseline dan target arsitektur dan melakukan gap analisis antara baseline arsitektur dengan target arsitektur

\section{Fase C: Information System Architecture}

Information system architecture terbagi menjadi 2 yaitu, Data Architecture dan Application Architecture. Fase ini merupakan pengembangan dari arsitektur sistem informasi untuk mendukung Fase A: Architecture Vision dan Fase B: Business Architecture, menetapkan baseline dan target arsitektur dan melakukan gap analisis antara baseline arsitektur dengan target arsitektur 
Meidiani Juwita Rachmawati ${ }^{1}$, Asti Amalia Nur Fajrillah ${ }^{2}$

@is The Best: Accounting Information Systems and Information Technology Business Enterprise

ISSN: 2252-9853 (Print) | ISSN: 2656-808X (Online)

\section{Fase D: Technology Architecture}

Mendefinisikan perkembangan arsitektur teknologi untuk mendukung Fase A: Architecture Vision, Fase B: Business Architecture dan Fase C: Information System Architecture, menetapkan baseline dan target arsitektur dan melakukan gap analisis antara baseline arsitektur dengan target arsitektur

6. Fase E: Opportunities and Solution

Mendefinisikan manfaat yang dihasilkan dari analisis dan perancangan pada fase A sampai dengan fase D, melakukan evaluasi perancangan model EA yang telah dibuat sehingga pemodelan arsitektur yang telah dirancang dapat sesuai dengan kondisi dan tujuan perusahaan

7. Fase F: Migration and Planning

Mengidentifikasi nilai dan risiko dari setiap proyek yang telah ditentukan untuk dijadikan pertimbangan penentuan skala prioritas proyek yang akan diimplementasikan

\section{Fase G: Implementation Governance}

Menyusun rencana kerja untuk mencapai arsitektur yang telah dibuat, memberikan pengawasan arsitektur dari implementasi

9. Fase H: Architecture Change Management

Memastikan perubahan pada arsitektur dapat dikelola dengan komprehensif dan arsitektur yang dibangun bersifat dinamis

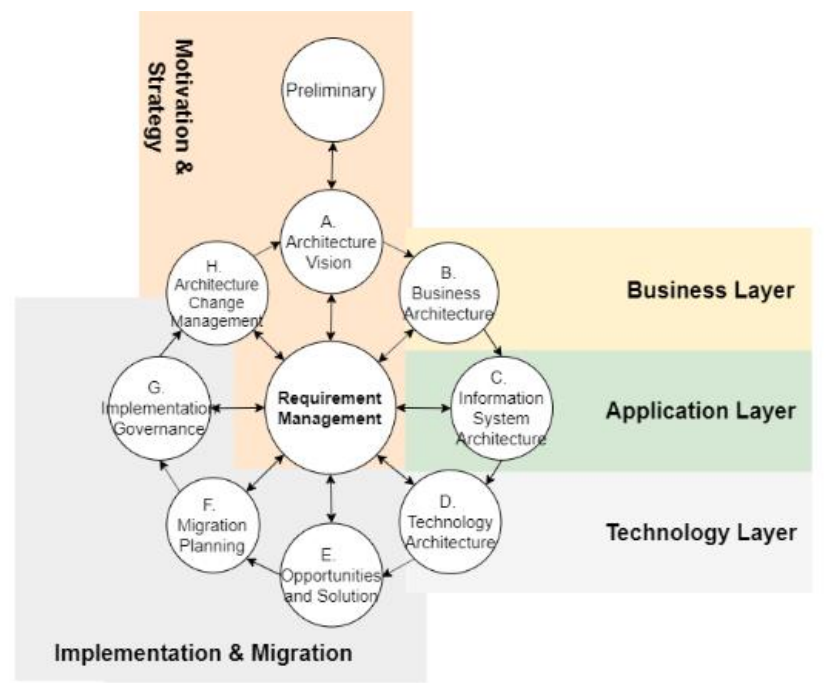

Gambar 1 Fase TOGAF ADM

\section{METODE PENELITIAN}

Penelitian ini dilakukan pada perusahaan manufaktur di Bandung yang memproduksi raw material s energi dan infrastruktur menjadi produk - produk komersial yang dipasarkan di seluruh Indonesia. Penelitian ini berfokus pada fungsi pengelolaan fasilitas. Fungsi pengelolaan fasilitas merupakan fungsi yang mengelola aset perusahaan, yang terdiri dari barang berjalan (mobil, motor, sepeda, gedung), dan barang inventaris kantor. Fungsi pengelolaan fasilitas memberikan pelayanan terkait aset - aset perusahaan. Fungsi ini berhubungan dengan seluruh fungsi yang ada pada perusahaan. Penelitian ini menggunakan kerangka kerja TOGAF ADM dan menggunakan model konseptual untuk menggambarkan langkah - langkah perancangan enterprise architecture. Metode yang digunakan pada penelitian ini adalah metode descriptive. Pada metode ini, dilakukan identifikasi 
permasalahan serta kondisi perusahaan saat ini melalui wawancara dengan staf dari fungsi pengelolaan fasilitas dan studi literatur dokumen yang terkait dengan penelitian ini.

Langkah awal dalam perancangan EA adalah mempelajari dan mencari informasi yang berkaitan dengan perancangan, seperti mengenai EA TOGAF ADM dan dokumen - dokumen perusahaan yang dibutuhkan untuk perancangan EA yaitu, dokumen Annual Report, Rencana Jangka Panjang Perusahaan (RJPP), Rencana Keuangan dan Anggaran Perusahaan (RKAP), Standard Operating Procedure (SOP), dan Key Performance Indicator (KPI). Selain dokumen - dokumen penunjang tersebut, dilakukan juga observasi melalui wawancara kepada pihak perusahaan yang terlibat dalam perancangan EA untuk mengidentifikasikan masalah yang terjadi pada fungsi pengelolaan fasilitas. Wawancara ini bertujuan untuk memvalidasi data dan mencari informasi tambahan yang tidak dapat ditemukan dari dokumen - dokumen perusahaan.

Hasil observasi tersebut digambarkan kedalam artefak - artefak dari fase dalam TOGAF ADM. Penggambaran artefak dimulai dari preliminary phase, fase A: Architecture Vision, dan fase B: Business Architecture.

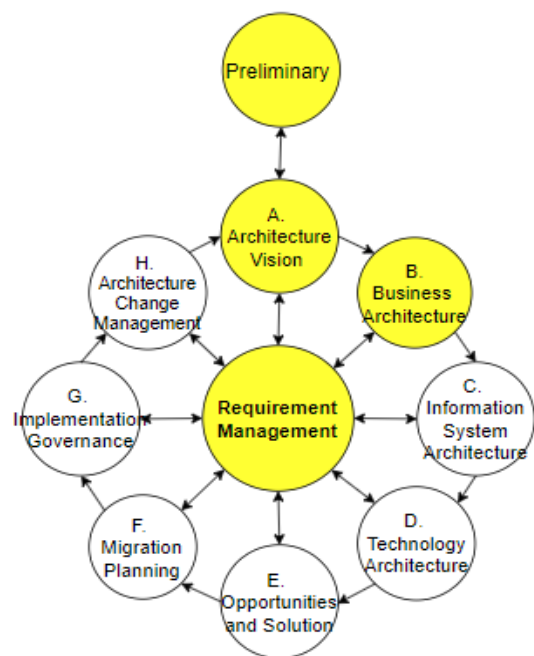

Gambar 2 Penggambaran fase TOGAF pada penelitian ini

\section{HASIL DAN PEMBAHASAN}

\section{Value Chain Analysis}

Value Chain merupakan serangkaian aktivitas yang digunakan untuk mendesain, memproduksi, memasarkan, mengirim dan mendukung produk untuk menciptakan value bagi pelanggan[21]. Aktivitas penciptaan value bagi pelanggan saling terhubung dan mempengaruhi. Satu aktivitas dapat mempengaruhi biaya atau kinerja yang lain[22]. Value Chain merupakan metodologi yang kuat untuk mengeksplorasi berbagai aspek dari perusahaan yang berguna untuk proses analisis alur materi atau siklus hidup dengan penerapan yang luas[23]. Value chain terbagi menjadi 2 bagian yaitu, primary activity (fungsi utama) dan support activity (fungsi pendukung). 
Meidiani Juwita Rachmawati ${ }^{1}$, Asti Amalia Nur Fajrillah ${ }^{2}$

@ is The Best: Accounting Information Systems and Information Technology Business Enterprise ISSN: 2252-9853 (Print) | ISSN: 2656-808X (Online)

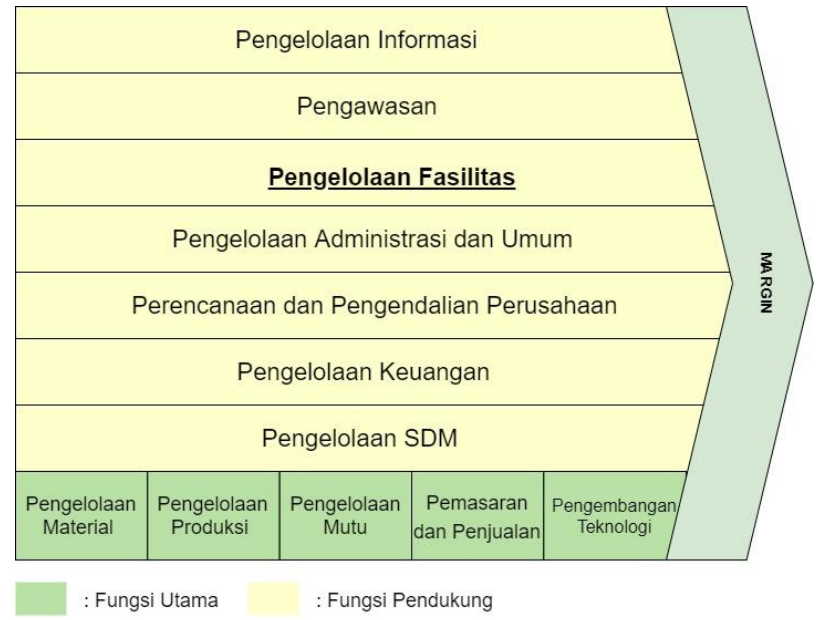

Gambar 3 Value Chain Diagram

Pada fungsi utama menggambarkan seluruh unit fungsi yang menjadi penggerak bisnis perusahaan. Pada fungsi pendukung menggambarkan seluruh fungsi yang menjadi pendorong keberhasilan untuk fungsi utama. Terdapat 5 fungsi pada fungsi utama dan 7 fungsi pada fungsi pendukung. Fungsi pengelolaan fasilitas berada pada bagian fungsi pendukung.

\section{Proses Bisnis dan Aplikasi pada Fungsi Pengelolaan Fasilitas}

Proses bisnis pada Tabel 1 Proses Bisnis dan Aplikasi menggambarkan proses kegiatan yang dilakukan oleh seluruh staf dari fungsi pengelolaan fasilitas beserta aplikasi atau tools yang digunakan untuk menunjang kegiatannya. Penjabaran proses bisnis dengan aplikasi yang digunakan menjelaskan mengenai fungsionalitas aplikasi pada fungsi pengelolaan fasilitas.

Tabel 1 Proses Bisnis dan Aplikasi

\begin{tabular}{|c|c|c|c|}
\hline Proses Bisnis & Deskripsi & Alur Proses & Aplikasi \\
\hline Inventarisasi & $\begin{array}{l}\text { Proses } \\
\text { pendataan aset } \\
\text { yang dilakukan } \\
\text { per tahun pada } \\
\text { setiap fungsi }\end{array}$ & $\begin{array}{l}\text { Proses dimulai ketika staf } \\
\text { pengelolaan fasilitas melakukan } \\
\text { pendataan seluruh aset yang } \\
\text { dimiliki oleh perusahaan dari } \\
\text { SAP FI kemudian data dibagikan } \\
\text { kepada seluruh fungsi untuk di } \\
\text { validasi kesesuaiannya. } \\
\text { Kemudian setiap fungsi } \\
\text { memvalidasi data tersebut yang } \\
\text { selanjutnya dibuatkan berita } \\
\text { acara telah melakukan } \\
\text { inventarisasi yang diberikan } \\
\text { kepada staf pengelolaan fasilitas. } \\
\text { Setelah dokumen diterima, staf } \\
\text { pengelolaan fasilitas membuat } \\
\text { laporan inventarisasi yang } \\
\text { kemudian dikirimkan kepada } \\
\text { Direktur Utama }\end{array}$ & $\begin{array}{c}\text { Microsoft Excel, } \\
\text { Microsoft Word, } \\
\text { E-mail, SAP } \\
\text { FI }\end{array}$ \\
\hline
\end{tabular}


Meidiani Juwita Rachmawati ${ }^{1}$, Asti Amalia Nur Fajrillah ${ }^{2}$

@is The Best: Accounting Information Systems and Information Technology Business Enterprise ISSN: 2252-9853 (Print) | ISSN: 2656-808X (Online)

\begin{tabular}{|c|c|c|c|}
\hline Proses Bisnis & Deskripsi & Alur Proses & Aplikasi \\
\hline $\begin{array}{l}\text { Pengajuan } \\
\text { Asuransi Aset }\end{array}$ & $\begin{array}{l}\text { Proses } \\
\text { pendataan aset } \\
\text { yang akan } \\
\text { diasuransikan }\end{array}$ & $\begin{array}{l}\text { Proses dimulai ketika staf } \\
\text { pengelolaan fasilitas mengirim } \\
\text { surat himbauan untuk mendata } \\
\text { aset yang akan diasuransikan } \\
\text { kepada setiap fungsi. Setelah } \\
\text { dilakukan pendataan oleh masing } \\
\text { - masing fungsi, kemudian setiap } \\
\text { fungsi mengirimkan data aset } \\
\text { kepada staf pengelolaan fasilitas. } \\
\text { Selanjutnya staf pengelolaan } \\
\text { fasilitas merekap data tersebut } \\
\text { kemudian membuat dokumen } \\
\text { Permintaan Material atau Jasa } \\
\text { (PMJ) untuk pengajuan asuransi } \\
\text { aset kepada divisi supply chain. } \\
\text { Selanjutnya divisi supply chain } \\
\text { memberikan asuransi polis untuk } \\
\text { setiap aset yang diajukan } \\
\text { asuransinya kepada staf } \\
\text { pengelolaan fasilitas }\end{array}$ & $\begin{array}{l}\text { Telepon, } \\
\text { Surat }\end{array}$ \\
\hline $\begin{array}{l}\text { Pengajuan klaim } \\
\text { asuransi aset }\end{array}$ & $\begin{array}{l}\text { Proses } \\
\text { pengajuan polis } \\
\text { asuransi untuk } \\
\text { aset yang rusak }\end{array}$ & $\begin{array}{l}\text { Proses dimulai ketika adanya } \\
\text { permintaan pengajuan klaim } \\
\text { asuransi dari setiap fungsi } \\
\text { dengan memberikan dokumen } \\
\text { kronologi kerusakan aset yang } \\
\text { diterima staf pengelolaan fasilitas } \\
\text { kemudian staf pengelolaan } \\
\text { fasilitas mengirimkan kronologi } \\
\text { kerusakan tersebut kepada pihak } \\
\text { asuransi. Pihak asuransi akan } \\
\text { menginformasikan informasi } \\
\text { mengenai persetujuan klaim } \\
\text { tersebut. }\end{array}$ & $\begin{array}{l}\text { Telepon, } \\
\text { E-mail }\end{array}$ \\
\hline $\begin{array}{c}\text { Pengembalian } \\
\text { Aset }\end{array}$ & $\begin{array}{l}\text { Proses } \\
\text { pengembalian } \\
\text { aset yang sudah } \\
\text { tidak terpakai } \\
\text { maupun aset } \\
\text { yang rusak }\end{array}$ & $\begin{array}{l}\text { Proses dimulai ketika terdapat } \\
\text { salah satu fungsi yang } \\
\text { menginformasikan adanya aset } \\
\text { yang akan dikembalikan, staf } \\
\text { pengelolaan fasilitas menerima } \\
\text { aset yang dikembalikan beserta } \\
\text { dokumen Perpindahan Aset } \\
\text { Tetap (PAT) kemudian staf } \\
\text { pengelolaan fasilitas melakukan } \\
\text { perubahan status pada SAP FI }\end{array}$ & $\begin{array}{c}\text { Telepon, } \\
\text { Surat, SAP FI }\end{array}$ \\
\hline
\end{tabular}


Meidiani Juwita Rachmawati ${ }^{1}$, Asti Amalia Nur Fajrillah ${ }^{2}$

@is The Best: Accounting Information Systems and Information Technology Business Enterprise ISSN: 2252-9853 (Print) | ISSN: 2656-808X (Online)

\begin{tabular}{|c|c|c|c|}
\hline Proses Bisnis & Deskripsi & Alur Proses & Aplikasi \\
\hline $\begin{array}{c}\text { Penyewaan } \\
\text { Gedung \& } \\
\text { Penyewaan Mesin }\end{array}$ & $\begin{array}{l}\text { Proses } \\
\text { penyewaan } \\
\text { gedung dan } \\
\text { mesin yang } \\
\text { sedang tidak } \\
\text { digunakan } \\
\text { kepada pihak } \\
\text { eksternal }\end{array}$ & $\begin{array}{l}\text { Proses dimulai ketika divisi bisnis } \\
\text { industrial menanyakan } \\
\text { ketersediaan mesin dan/atau } \\
\text { gedung. Selanjutnya staf } \\
\text { pengelolaan aset melakukan } \\
\text { pengecekan terhadap } \\
\text { permintaan. Jika gedung tersedia, } \\
\text { staf pengelolaan fasilitas akan } \\
\text { memberikan informasi nilai } \\
\text { gedung dan/atau mesin. Jika } \\
\text { divisi bisnis industrial menyetujui } \\
\text { harga yang diberikan dan } \\
\text { mengajukan kerja sama } \\
\text { peminjaman gedung dan/tau } \\
\text { mesin maka staf pengelolaan } \\
\text { fasilitas akan membuatkan } \\
\text { kontrak kerja sama kemudian } \\
\text { kontrak tersebut diserahkan } \\
\text { kepada divisi akuntansi dan } \\
\text { keuangan untuk dibuatkan invoice } \\
\text { penyewaan. Invoice tersebut } \\
\text { dikirim kepada staf pengelolaan } \\
\text { fasilitas. Selanjutnya salinan } \\
\text { kontrak kerja sama dan invoice } \\
\text { sewa diserahkan kepada divisi } \\
\text { bisnis industrial. }\end{array}$ & $\begin{array}{c}\text { Microsoft Excel, } \\
\text { Telepon, } \\
\text { Surat }\end{array}$ \\
\hline $\begin{array}{c}\text { Pemanfaatan Aset } \\
\text { yang Tidak } \\
\text { Terpakai }\end{array}$ & $\begin{array}{l}\text { Proses } \\
\text { permintaan aset } \\
\text { yang sedang } \\
\text { tidak digunakan }\end{array}$ & $\begin{array}{l}\text { Proses dimulai saat salah satu } \\
\text { fungsi menanyakan ketersediaan } \\
\text { aset yang dibutuhkan, kemudian } \\
\text { staf pengelolaan fasilitas } \\
\text { melakukan pengecekan aset yang } \\
\text { dibutuhkan. Jika tersedia maka } \\
\text { fungsi tersebut diminta untuk } \\
\text { membuat dan mengirimkan surat } \\
\text { permintaan aset yang ditujukan } \\
\text { kepada Manager Pengelolaan } \\
\text { dan Pemeliharaan Aset tetap. } \\
\text { Jika permintaan disetujui oleh } \\
\text { Manager, maka staf pengelolaan } \\
\text { fasilitas akan membuatkan } \\
\text { dokumen PAT kemudian staf } \\
\text { pengelolaan fasilitas akan } \\
\text { mengirimkan aset yang diminta } \\
\text { beserta dokumen PAT } \\
\text { selanjutnya staf pengelolaan aset }\end{array}$ & $\begin{array}{c}\text { Telepon, } \\
\text { Surat, SAP FI }\end{array}$ \\
\hline
\end{tabular}


Meidiani Juwita Rachmawati ${ }^{1}$, Asti Amalia Nur Fajrillah ${ }^{2}$

@is The Best: Accounting Information Systems and Information Technology Business Enterprise

ISSN: 2252-9853 (Print) | ISSN: 2656-808X (Online)

\begin{tabular}{|l|c|l|c|}
\hline Proses Bisnis & Deskripsi & \multicolumn{1}{|c|}{ Alur Proses } & Aplikasi \\
\hline & & $\begin{array}{l}\text { akan meng-update status aset } \\
\text { pada SAP FI }\end{array}$ & \\
\hline
\end{tabular}

\section{Permasalahan yang Dihadapi}

Dalam proses observasi, ditemukan beberapa kendala yang dihadapi oleh fungsi pengelolaan fasilitas. Permasalahan yang dihadapi mempengaruhi kinerja fungsi pengelolaan fasilitas karena permasalahan yang ada saling berkaitan dengan proses bisnis yang dimiliki. Pemetaan permasalahan dengan proses bisnis dijabarkan pada Tabel 2 Permasalahan yang dihadapi fungsi pengelolaan fasilitas.

Tabel 2 Permasalahan yang dihadapi fungsi pengelolaan fasilitas

\begin{tabular}{|c|c|c|}
\hline Permasalahan & Deskripsi & $\begin{array}{c}\text { Proses Bisnis yang } \\
\text { Terkait }\end{array}$ \\
\hline \multirow[b]{3}{*}{ Kontrol Aset } & \multirow{3}{*}{$\begin{array}{l}\text { Tidak sinkronnya data aset pada sistem } \\
\text { dengan aset yang ada pada lapangan } \\
\text { terdapat sebanyak } 50 \% \text { yang tidak sinkron } \\
\text { setiap tahunnya }\end{array}$} & Inventarisasi \\
\hline & & Pengembalian Aset \\
\hline & & $\begin{array}{c}\text { Pemanfaatan Aset yang } \\
\text { Tidak terpakai }\end{array}$ \\
\hline \multirow[b]{3}{*}{$\begin{array}{l}\text { Kebutuhan } \\
\text { Aplikasi }\end{array}$} & \multirow{3}{*}{$\begin{array}{l}\text { Hanya terdapat } 1 \text { aplikasi dan belum } \\
\text { mencukupi untuk menunjang kegiatan } \\
\text { yang ada di fungsi pengelolaan fasilitas. } \\
\text { Kegiatan masih mengandalkan Microsoft } \\
\text { word, Microsoft excel, e-mail, surat-menyurat } \\
\text { manual dan telepon sehingga prosesnya } \\
\text { membutuhkan waktu yang lebih lama dan } \\
\text { rawan kehilangan data }\end{array}$} & Pengajuan Asuransi Aset \\
\hline & & $\begin{array}{c}\text { Pengajuan Klaim } \\
\text { Asuransi Aset }\end{array}$ \\
\hline & & $\begin{array}{l}\text { Penyewaan Gedung \& } \\
\text { Penyewaan Mesin }\end{array}$ \\
\hline
\end{tabular}

\section{GAP Analysis}

Gap Analysis merupakan proses identifikasi kesenjangan kondisi proses dan aplikasi saat ini untuk mencapai goal pada fungsi pengelolaan fasilitas. Indikator analisis adalah target fungsi pengelolaan fasilitas yang harus dicapai 5 tahun ke depan. Pemaparan goal, objective dan requirement didasarkan pada dokumen KPI fungsi pengelolaan fasilitas dan dokumen RJPP perusahaan. Untuk mencapai goal, fungsi pengelolaan fasilitas harus memenuhi objective dan requirement yang telah dijabarkan pada dokumen KPI perusahaan. Goal dapat dikatakan tercapai jika terpenuhinya requirement dan objective. 
Meidiani Juwita Rachmawati ${ }^{1}$, Asti Amalia Nur Fajrillah ${ }^{2}$

@is The Best: Accounting Information Systems and Information Technology Business Enterprise

ISSN: 2252-9853 (Print) | ISSN: 2656-808X (Online)

Tabel 3 Requirement Catalog

\begin{tabular}{|c|c|c|c|c|}
\hline \multicolumn{3}{|c|}{ Target Perusahaan } & \multirow{2}{*}{ Kondisi Saat Ini } & \multirow{2}{*}{ Analisis } \\
\hline Goal & Objective & Requirement & & \\
\hline \multirow{4}{*}{$\begin{array}{l}\text { Terciptanya } \\
\text { pelayanan } \\
\text { yang } \\
\text { berkualitas, } \\
\text { efektif, } \\
\text { efisien dan } \\
\text { tepat waktu }\end{array}$} & \multirow[b]{2}{*}{$\begin{array}{l}\text { Meningkatkan } \\
\text { proses } \\
\text { pelayanan }\end{array}$} & $\begin{array}{l}\text { Adanya proses } \\
\text { pengelolaan } \\
\text { administrasi data } \\
\text { dan permintaan } \\
\text { layanan yang baik }\end{array}$ & $\begin{array}{l}\text { Proses pengelolaan } \\
\text { administrasi dan } \\
\text { permintaan } \\
\text { layanan masih } \\
\text { manual }\end{array}$ & $\begin{array}{l}\text { Proses yang } \\
\text { masih manual } \\
\text { menyebabkan } \\
\text { waktu } \\
\text { pengerjaan } \\
\text { layanan yang } \\
\text { lama }\end{array}$ \\
\hline & & $\begin{array}{l}\text { Adanya tingkat } \\
\text { prioritas } \\
\text { proses pemberian } \\
\text { layanan }\end{array}$ & $\begin{array}{l}\text { Tidak adanya } \\
\text { prioritas dalam } \\
\text { setiap permintaan } \\
\text { layanan sehingga } \\
\text { proses pengerjaan } \\
\text { layanan dilakukan } \\
\text { dengan metode } \\
\text { first in, first out }\end{array}$ & $\begin{array}{l}\text { Tidak adanya } \\
\text { proses } \\
\text { pemberian } \\
\text { prioritas } \\
\text { menyebabkan } \\
\text { permintaan } \\
\text { layanan yang } \\
\text { penting menjadi } \\
\text { terhambat }\end{array}$ \\
\hline & \multirow[b]{2}{*}{$\begin{array}{lr}\text { Proses } & \text { bisnis } \\
\text { yang } & \text { tepat } \\
\text { sasaran } & \end{array}$} & $\begin{array}{l}\text { Adanya SOP dalam } \\
\text { proses permintaan } \\
\text { layanan dan } \\
\text { pelaksanaan } \\
\text { kegiatan }\end{array}$ & $\begin{array}{l}\text { Tidak adanya SOP } \\
\text { pada fungsi } \\
\text { pengelolaan } \\
\text { fasilitas }\end{array}$ & $\begin{array}{l}\text { Tidak adanya } \\
\text { standar kerja } \\
\text { yang paten } \\
\text { menyebabkan } \\
\text { tidak tertatanya } \\
\text { penanganan } \\
\text { layanan }\end{array}$ \\
\hline & & $\begin{array}{l}\text { Adanya aplikasi } \\
\text { penunjang dalam } \\
\text { proses kegiatan } \\
\text { pelayanan aset }\end{array}$ & $\begin{array}{l}\text { Aplikasi yang } \\
\text { digunakan adalah } \\
\text { Microsoft word, } \\
\text { Microsoft excel, e-mail } \\
\text { dan SAP FI }\end{array}$ & $\begin{array}{l}\text { Aplikasi } \\
\text { penunjang tidak } \\
\text { cukup untuk } \\
\text { menunjang } \\
\text { seluruh proses } \\
\text { bisnis yang ada } \\
\text { pada fungsi } \\
\text { pengelolaan } \\
\text { fasilitas }\end{array}$ \\
\hline $\begin{array}{l}\text { Terciptanya } \\
\text { kesesuaian } \\
\text { antara data } \\
\text { di lapangan } \\
\text { dan pada } \\
\text { sistem }\end{array}$ & $\begin{array}{l}\text { Pemanfaatan } \\
\text { Aset Tetap }\end{array}$ & $\begin{array}{l}\text { Tercatatnya seluruh } \\
\text { permintaan } \\
\text { pengoptialisasian } \\
\text { aset }\end{array}$ & $\begin{array}{l}\text { Terdapat } \\
\text { pencatatan } \\
\text { pengoptimalisasian } \\
\text { aset yaitu } \\
\text { menggunakan } \\
\text { Microsoft excel }\end{array}$ & $\begin{array}{l}\text { Proses } \\
\text { pencatatan aset } \\
\text { yang manual } \\
\text { memungkinkan } \\
\text { untuk } \\
\text { menyebabkan } \\
\text { terjadinya buman } \\
\text { error berupa } \\
\text { kesalahan } \\
\text { pencatatan } \\
\text { maupun tidak } \\
\text { tercatatnya aset }\end{array}$ \\
\hline
\end{tabular}


Meidiani Juwita Rachmawati ${ }^{1}$, Asti Amalia Nur Fajrillah ${ }^{2}$

@is The Best: Accounting Information Systems and Information Technology Business Enterprise ISSN: 2252-9853 (Print) | ISSN: 2656-808X (Online)

\begin{tabular}{|c|c|c|c|c|}
\hline \multicolumn{3}{|c|}{ Target Perusahaan } & \multirow{2}{*}{ Kondisi Saat Ini } & \multirow{2}{*}{ Analisis } \\
\hline Goal & Objective & Requirement & & \\
\hline & & & & $\begin{array}{l}\text { yang } \\
\text { dioptimalisasikan }\end{array}$ \\
\hline & $\begin{array}{l}\text { Meningkatkan } \\
\text { pelaporan dan } \\
\text { transparansi }\end{array}$ & $\begin{array}{l}\text { Terdokumentasinya } \\
\text { seluruh aset pada } \\
\text { perusahaan }\end{array}$ & $\begin{array}{l}\text { Masih terdapat } \\
\text { aset yang tidak } \\
\text { terdokumentasi }\end{array}$ & $\begin{array}{l}\text { Adanya aset yang } \\
\text { tidak } \\
\text { terdokumentasi } \\
\text { disebabkan } \\
\text { karena terdapat } 2 \\
\text { penyimpanan } \\
\text { data yaitu SAP FI } \\
\text { dan Microsoft excel } \\
\text { yang } \\
\text { menyebabkan } \\
\text { proses } \\
\text { inventarisasi } \\
\text { yang kurang baik }\end{array}$ \\
\hline
\end{tabular}

\section{Perancangan Arsitektur Bisnis}

Berdasarkan hasil analisis, khususnya pada bagian analisis kesenjangan, fungsi pengelolaan fasilitas masih sulit untuk mencapai goal-nya karena belum terpenuhinya keseluruhan objective maupun requirement yang perlu dicapai. Untuk dapat mencapainya, fungsi pengelolaan fasilitas memerlukan sebuah dokumen pedoman kerja dan aplikasi yang dapat mendukung seluruh kegiatan dan menjadi solusi atas permasalahan yang dihadapi. Tabel 4 Perancangan Arsitektur Bisnis menjelaskan hubungan goal fungsi dengan penjabaran solusi yang diberikan.

Tabel 4 Perancangan Arsitektur Bisnis

\begin{tabular}{|c|c|}
\hline $\begin{array}{c}\text { Goal Fungsi Pengelolaan } \\
\text { Fasilitas }\end{array}$ & Solusi \\
\hline $\begin{array}{l}\text { Terciptanya pelayanan yang } \\
\text { berkualitas, efektif, efisien dan } \\
\text { tepat waktu }\end{array}$ & $\begin{array}{l}\text { 1. Dibuatnya standar kerja atau SOP untuk } \\
\text { setiap proses bisnis pada fungsi pengelolaan } \\
\text { fasilitas sehingga tertatanya seluruh proses } \\
\text { pengerjaan aktivitas } \\
\text { 2. Dibuatnya aplikasi yang dapat menunjang } \\
\text { proses kegiatan fungsi pengelolaan fasilitas. } \\
\text { Pada aplikasi tersebut dibutuhkan fitur } \\
\text { penilaian pelayanan yang diberikan, } \\
\text { sehingga setiap staf pada fungsi pengelolaan } \\
\text { fasilitas dapat mengetahui proses - proses }\end{array}$ \\
\hline $\begin{array}{l}\text { Terciptanya keses } \\
\text { di lapangan dan } p\end{array}$ & \\
\hline
\end{tabular}


Tabel 5 Proses Bisnis Usulan merupakan penjabaran solusi aplikasi terhadap proses bisnis pada fungsi pengelolaan fasilitas. Terdapat beberapa perubahan dan percepatan proses pada proses bisnis usulan.

Tabel 5 Proses Bisnis Usulan

\begin{tabular}{|c|c|c|}
\hline Proses Bisnis & Proses Bisnis Saat Ini & Perubahan Proses Bisnis \\
\hline Inventarisasi & $\begin{array}{l}\text { - Staf pengelolaan } \\
\text { fasilitas mengirimkan } \\
\text { data aset melalui e-mail } \\
\text { kepada seluruh fungsi } \\
\text { di perusahaan } \\
\text { - Data hasil inventarisasi } \\
\text { setiap fungsi } \\
\text { dikembalikan } \\
\text { menggunakan e-mail } \\
\text { Laporan inventarisasi } \\
\text { dilakukan } \\
\text { menggunakan Microsoft } \\
\text { word }\end{array}$ & $\begin{array}{l}\text { - Staf pengelolaan } \\
\text { fasilitas } \\
\text { menginformasikan } \\
\text { proses inventarisasi } \\
\text { melalui aplikasi } \\
\text { - Proses inventarisasi } \\
\text { dilakukan dalam } \\
\text { aplikasi pengelolaan } \\
\text { - Staf dapat } \\
\text { fasilitas laporan } \\
\text { mengunduh larisi } \\
\text { hasil inventarisasi } \\
\text { melalui aplikasi }\end{array}$ \\
\hline $\begin{array}{c}\text { Pengajuan } \\
\text { Asuransi Aset }\end{array}$ & $\begin{array}{l}\text { - Staf pengelolaan } \\
\text { fasilitas mengirim surat } \\
\text { himbauan } \\
\text { menggunakan e-mail, } \\
\text { telepon atau surat } \\
\text { - Proses pendataan aset } \\
\text { yang akan } \\
\text { diasuransikan } \\
\text { dilakukan dengan } \\
\text { Microsoft excel } \\
\text { - Setiap fungsi harus } \\
\text { mengirimkan data aset } \\
\text { yang akan } \\
\text { diasuransikan } \\
\text { menggunakan e-mail } \\
\text { Staf fungsi pengelolaan } \\
\text { fasilitas perlu } \\
\text { melakukan perekapan } \\
\text { data }\end{array}$ & 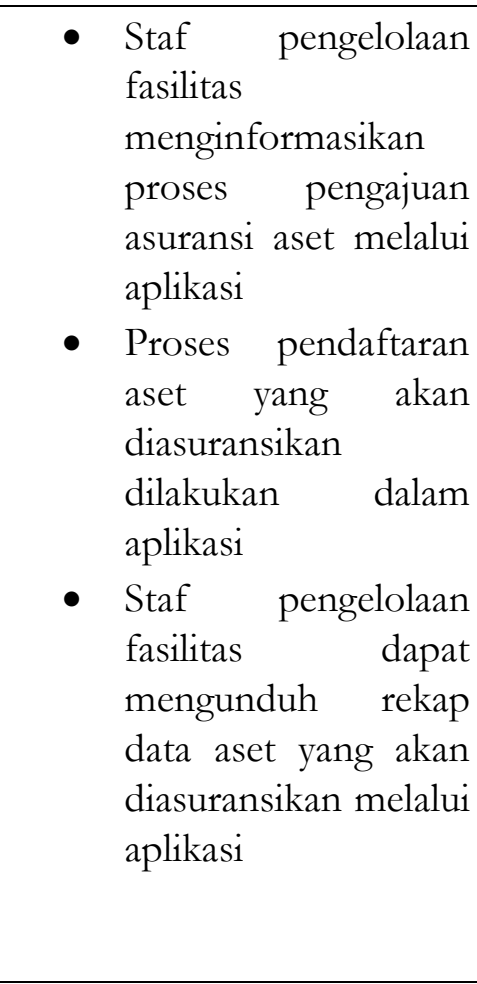 \\
\hline $\begin{array}{l}\text { Pengajuan klaim } \\
\text { asuransi aset }\end{array}$ & $\begin{array}{lr}\text { - Salah satu fungsi } \\
\text { menelfon } & \text { atau } \\
\text { mengirimkan } & \text { surat } \\
\text { kepada staf pengelolaan } \\
\text { fasilitas }\end{array}$ & $\begin{array}{l}\text { - Staf dari salah satu } \\
\text { fungsi memasukan } \\
\text { data aset yang ingin di } \\
\text { klaim asuransinya } \\
\text { besertar kronologi }\end{array}$ \\
\hline
\end{tabular}


Meidiani Juwita Rachmawati ${ }^{1}$, Asti Amalia Nur Fajrillah ${ }^{2}$

@is The Best: Accounting Information Systems and Information Technology Business Enterprise ISSN: 2252-9853 (Print) | ISSN: 2656-808X (Online)

\begin{tabular}{|c|c|c|}
\hline Proses Bisnis & Proses Bisnis Saat Ini & Perubahan Proses Bisnis \\
\hline & $\begin{array}{l}\text { pengajuan klaim } \\
\text { asuransi aset dan } \\
\text { memberikan dokumen } \\
\text { kronologi kerusakan } \\
\text { fasilitas } \\
\text { - Staf pengelolaan } \\
\text { fasilitas } \\
\text { menindaklanjuti proses } \\
\text { klaim asuransi secara } \\
\text { melalui telefon ataupun } \\
\text { surat }\end{array}$ & $\begin{array}{l}\text { kerusakan aset } \\
\text { melalui aplikasi } \\
\text { - Staf pengelolaan } \\
\text { fasilitas menerima } \\
\text { dan menindaklanjuti } \\
\text { proses dalam aplikasi }\end{array}$ \\
\hline $\begin{array}{c}\text { Pengembalian } \\
\text { Aset }\end{array}$ & 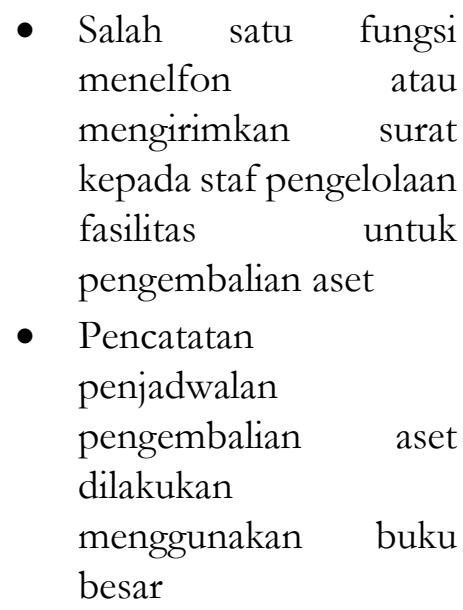 & $\begin{array}{l}\text { - Staf dari salah satu } \\
\text { fungsi memasukan } \\
\text { data aset yang ingin } \\
\text { mengembalikan aset } \\
\text { melalui aplikasi } \\
\text { - Staf pengelolaan } \\
\text { fasilitas menerima } \\
\text { permintaan aset } \\
\text { pengembalian an melakukan } \\
\text { dan proses } \\
\text { penjadwalan an aplikasi } \\
\text { dalam }\end{array}$ \\
\hline $\begin{array}{c}\text { Penyewaan } \\
\text { Gedung \& } \\
\text { Penyewaan Mesin }\end{array}$ & $\begin{array}{l}\text { - Staf bisnis industrial } \\
\text { melakukan pengecekan } \\
\text { terhadap aset yang } \\
\text { ingin disewa } \\
\text { menggunakan telepon } \\
\text { atau surat } \\
\text { - Staf pengelolaan } \\
\text { fasilitas mengecek } \\
\text { ketersediaan aset yang } \\
\text { akan disewa pada } \\
\text { microsoft excel } \\
\text { - Staf pengelolaan } \\
\text { fasilitas memberi } \\
\text { informasi ketersediaan } \\
\text { dan harga sewa } \\
\text { menggunakan telepon } \\
\text { atau surat } \\
\text { Permintan penyewaan } \\
\text { dilakukan melalui surat }\end{array}$ & $\begin{array}{l}\text { - Staf divisi bisnis } \\
\text { industrial melakukan } \\
\text { pengecekan terhadap } \\
\text { gedung atau mesin } \\
\text { yang tersedia beserta } \\
\text { harga sewa aset } \\
\text { melalui aplikasi } \\
\text { - Staf divisi bisnis } \\
\text { industrial melakukan } \\
\text { permintaan } \\
\text { penyewaan gedung } \\
\text { atau mesin dalam } \\
\text { aplikasi }\end{array}$ \\
\hline
\end{tabular}


Meidiani Juwita Rachmawati ${ }^{1}$, Asti Amalia Nur Fajrillah ${ }^{2}$

@is The Best: Accounting Information Systems and Information Technology Business Enterprise ISSN: 2252-9853 (Print) | ISSN: 2656-808X (Online)

\begin{tabular}{|c|c|c|}
\hline Proses Bisnis & Proses Bisnis Saat Ini & Perubahan Proses Bisnis \\
\hline & - Salah satu fungsi & Staf dari salah satu \\
& menanyakan & fungsi memasukan \\
& ketersediaan aset yang & data aset yang ingin \\
& dibutuhkan melalui & mengembalikan aset \\
Pemanfaatan Aset & telefon atau surat & melalui aplikasi \\
yang Tidak & - Staf pengelolaan & - Staf pengelolaan \\
Terpakai & fasilitas melakukan & fasilitas menerima \\
& proses pengerjaan & dan menindaklanjuti \\
& pemanfaatan aset yang & proses dalam aplikasi \\
& tidak terpakai secara & \\
& manual & \\
\hline
\end{tabular}

\section{Penutup}

Perancangan EA pada penelitian ini menggunakan framework TOGAF ADM dan berfokus pada perancangan arsitektur bisnis. Penelitian ini menghasilkan sebuah perancangan untuk fase arsitektur bisnis. Perancangan EA menggunakan framework. TOGAF ADM yang berfokus pada perancangan arsitektur bisnis ini diharapkan dapat membantu untuk mencapai goal fungsi pengelolaan fasilitas dalam jangka 5 tahun ke depan. Permasalahan yang didapat dari hasil penelitian ini adalah kontrol aset yaitu tidak sinkronnya data aset pada sistem dengan aset yang ada pada lapangan dan kebutuhan akan aplikasi karena hanya terdapat 1 aplikasi dan seluruh prosesnya dikerjakan secara manual sehingga rawan kehilangan data.

Berdasarkan kesenjangan kondisi saat ini dengan goal yang harus dicapai dan permasalahan pada fungsi pengelolaan fasilitas, diusulkan beberapa solusi untuk membantu tercapainya goal dan menyelesaikan permasalahan pada fungsi pengelolaan fasilitas yaitu dengan dibuatkannya SOP untuk kegiatan pada fungsi pengelolaan fasilitas dan pembuatan aplikasi untuk membantu dan mengoptimalisasikan proses bisnis pada pengelolaan fasilitas.

\section{DAFTAR PUSTAKA}

[1] H. Lindawati and I. Salamah, "Pemanfaatan Sistem Informasi dan Teknologi Informasi Pengaruhnya Terhadap Kinerja Individual Karyawan," J. Akunt. dan Kenang., vol. 14, no. 1, pp. 56-67, 2011, doi: 10.9744/jak.14.1.56-68.

[2] B. Lydon, "Industry 4.0: Intelligent and flexible production." InTech: A publication of the International Society of Automation," Int. Soc. Autom., 2016.

[3] E. Hozdić, "Smart factory for industry 4.0: A review," Int. J. Mod. Manuf. Technol., vol. 7, no. 1, pp. 28-35, 2015.

[4] S. K. Sari and A. Asniar, "Analisis Dan Pemodelan Proses Bisnis Prosedur Pelaksanaan Proyek Akhir Sebagai Alat Bantu Identifikasi Kebutuhan Sistem," J. INFOTEL - Inform. Telekomun. Elektron., vol. 7, no. 2, p. 143, 2015, doi: 10.20895/infotel.v7i2.42.

[5] N. A. A. Bakar, S. Harihodin, and N. Kama, "Assessment of Enterprise Architecture Implementation Capability and Priority in Public Sector Agency," Procedia Comput. Sci., vol. 100, pp. 198-206, 2016, doi: 10.1016/j.procs.2016.09.141.

[6] S. Rahayu and A. Hadiana, "Perancangan Enterprise Architecture Berbasis Service Menggunakan Zachman Framework: Studi Kasus PDAM Kota Sukabumi," J. Teknol. 
Meidiani Juwita Rachmawati ${ }^{1}$, Asti Amalia Nur Fajrillah ${ }^{2}$

@is The Best: Accounting Information Systems and Information Technology Business Enterprise

ISSN: 2252-9853 (Print) | ISSN: 2656-808X (Online)

Rekayasa, vol. 1, no. 1, p. 59, 2017, doi: 10.31544/jtera.v1.i1.2016.59-66.

[7] J. A. Espinosa, W. F. Boh, and W. DeLone, "The organizational impact of enterprise architecture: A research framework," Proc. Annu. Hawaii Int. Conf. Syst. Sci., pp. 1-10, 2011, doi: 10.1109/HICSS.2011.425.

[8] S. Lusa and D. I. Sensuse, "Kajian Perkembangan Dan Usulan Perancangan Enterprise Architecture Framework," Semin. Nas. Apl. Teknol. Inf., vol. 2011, no. Snati, pp. 17-18, 2011.

[9] R. E. Riwanto and J. F. Andry, "Enterprise Architectures Enable of Business Strategy and IS/IT Alignment in Manufacturing using TOGAF ADM Framework," Int. J. Inf. Technol. Bus., vol. 1, no. 2, pp. 1-2, 2019.

[10] T. Tamm, P. B. Seddon, G. Shanks, and P. Reynolds, "How does enterprise architecture add value to organisations?," Commun. Assoc. Inf. Syst., vol. 28, no. 1, pp. 141-168, 2011, doi: 10.17705/1cais.02810.

[11] H. Safari, Z. Faraji, and S. Majidian, "Identifying and evaluating enterprise architecture risks using FMEA and fuzzy VIKOR," J. Intell. Manuf., vol. 27, no. 2, pp. 475-486, 2016, doi: 10.1007/s10845-014-0880-0.

[12] B. M., "Enterprise Architecture Frameworks: A Critique Review from a Security Perspective," Int. J. Comput. Appl., vol. 174, no. 5, pp. 9-15, 2017, doi: 10.5120/ijca2017915416.

[13] R. Weisman, “An Overview of TOGAF Version 9.1,” Publ. by Open Gr., p. 43, 2011.

[14] C. K. Sastradipraja, D. Gustian, and S. D. Antadipura, "Perencanaan Strategi Sistem Informasi Penjualan Menggunakan Pendekatan Togaf Adm ( Studi Kasus : Three Sister's House Of Beauty )," vol. 04, no. 2019, pp. 8-11, 2020, doi: 10.34010/aisthebest.v4i02.2332.

[15] M. Taleb and O. Cherkaoui, "Pattern-oriented approach for enterprise architecture: Togaf framework," Des. Enterp. Archit. Fram. Integr. Bus. Process. with IT Infrastruct., no. January, pp. 99-113, 2016, doi: 10.4236/jsea.2012.51008.

[16] G. F. Nama, Tristiyanto, and Di. Kurniawan, "An enterprise architecture planning for higher education using the open group architecture framework (togaf): Case study University of Lampung," Proc. 2nd Int. Conf. Informatics Comput. ICIC 2017, vol. 2018-January, pp. 1-6, 2018, doi: 10.1109/IAC.2017.8280610.

[17] Object Management Group, "GRAPHICAL NOTATIONS FOR BUSINESS PROCESSES.”.

[18] The Open Group Architecture Framework, "Introduction to the ADM," The Open Group Publications Catalog. .

[19] D. Proenca and J. Borbinha, "Enterprise architecture: A maturity model based on TOGAF ADM," Proc. - 2017 IEEE 19th Conf. Bus. Informatics, CBI 2017, vol. 1, pp. 257-266, 2017, doi: 10.1109/CBI.2017.38.

[20] The Open Group Architecture Framework, "Architectural Artifacts," The Open Group Publications Catalog. .

[21] T. Koc and E. Bozdag, "Measuring the degree of novelty of innovation based on Porter's value chain approach," Eur. J. Oper. Res., vol. 257, no. 2, pp. 559-567, 2017, doi: 10.1016/j.ejor.2016.07.049.

[22] T. Y. Hsiao and C. M. Chuang, "Creating Shared Value Through Implementing Green Practices for Star Hotels," Asia Pacific J. Tour. Res., vol. 21, no. 6, pp. 678-696, 2016, doi: 10.1080/10941665.2015.1068194.

[23] D. Kumar, "Value Chain : A Conceptual Framework VALUE CHAIN : A CONCEPTUAL FRAMEWORK," no. October, 2018.

Volume 5 Nomor 1 (2020) Hal. 76-90

Attribution-ShareAlike 4.0 International. Some rights reserved 